\title{
UJI KARAKTERISTIK FISIS, pH DAN ORGANOLEPTIK SARI BUAH BELIMBING WULUH (Averrhoa bilimbi L.) DENGAN PENAMBAHAN PENGAWET SINTETIS DAN PENGAWET ALAMI
}

\author{
Sumardilan, Sri Fitria Retnowaty, Yulia Fitri, Aji Suroso \\ Program Studi Fisika, Fakultas MIPA dan Kesehatan \\ Universitas Muhammadiyah Riau
}

\begin{abstract}
ABSTRAK
Belimbing wuluh (Averrhoa bilimbi L.) merupakan salah satu spesies dalam family belimbing (Averrhoa). Belimbing wuluh kurang diminati oleh masyarakat jika dikonsumsi secara langsung karena rasanya yang sangat asam. Maka perlu melakukan pengolahan pada belimbing tersebut agar disukai oleh banyak orang. Salah satu caranya yaitu dengan membuat sari buah dari belimbing wuluh dengan penambahan gula dan diberi pengawet makanan agar dapat disimpan dalam jangka waktu yang lama. Untuk itu, maka dilakukan penelitian uji karakteristik fisis, $\mathrm{pH}$ dan organoleptik pada sari buah belimbing wuluh, agar dapat diketahui apakah ada perubahan Karakteristik fisis $\mathrm{pH}$ dan Organoleptik setelah diberikan penambahan gula, pengawet sintetis (natrium benzoat) dan pengawet alami (minyak cengkeh). Dan parameter fisis yang digunakan yaitu massa jenis, ORP (Oxidation Reduction Potential), TDS (Tottal Disolve Solid), salinitas, resistivitas, konduktivitas serta uji organoleptik berupa uji rasa, warna dan bau. Dari hasil penelitian di laboratorium menunjukkan jika semakin banyak penambahan pengawet sintetis maka nilai $\mathrm{pH}$, massa jenis, ORP TDS, salinitas, resistivitas dan konduktivitas semakin tinggi. Sedangkan semakin banyak penambahan pengawet alami maka nilai $\mathrm{pH}$, massa jenis, ORP TDS, salinitas, resistivitas dan konduktivitas semakin rendah. Hal tersebut disebabkan karena pengawet alami merupakan minyak yang mudah teroksidasi.
\end{abstract}

Kata kunci: Belimbing wuluh, pengawet, Uji Fisis, Uji pH, Uji Organoleptik

\section{PENDAHULUAN}

Belimbing wuluh (Averrhoa bilimbi L.) merupakan salah satu spesies dalam keluarga belimbing (Averrhoa). Tanaman ini tumbuh dengan baik di daerah Amerika Tropik, di Indonesia tanaman ini biasanya dipelihara di pekarangan dan dapat tumbuh sebagai tanaman liar [1].

Belimbing wuluh memiliki banyak manfaat diantaranya adalah untuk kesehatan, yaitu dimanfaatkan sebagai obat herbal yang dapat mengobati berbagai jenis penyakit seperti batuk, gondongan, rematik, diabetes, darah tinggi, sariawan, sakit perut, gusi berdarah, sakit gigi berlubang, dan memperbaiki fungsi pencernaan. Selain untuk kesehatan belimbing wuluh juga dapat digunakan untuk membersihkan noda pada kain, mencuci botol, mengkilapkan barangbarang yang terbuat dari kuningan, menghilangkan karat pada keris, menghilangkan bau amis, dan sebagai bahan kosmetika [1].
Belimbing wuluh kurang diminati oleh masyarakat jika dikonsumsi secara langsung karena rasanya yang sangat asam. Oleh karena itu perlu sedikit cara agar belimbing wuluh dapat digemari dan dikonsumsi oleh masyarakat. Caranya yaitu dibuat sari buah dengan penambahan gula dan diberi pengawet makanan agar sari buah dapat disimpan dalam jangka waktu yang lama.

Untuk itu, maka perlu dilakukan penelitian uji karakteristik fisis, $\mathrm{pH}$ dan organoleptik pada sari buah belimbing wuluh, agar dapat diketahui apakah ada perubahan setelah diberikan penambahan gula, pengawet sintetis (natrium benzoat) dan pengawet alami (minyak cengkeh). Menurut Epi Nuraeni dan Rince Mariance dari hasil penelitiannya menyatakan bahwa, perubahan nilai karakteristik fisis, $\mathrm{pH}$ dan organoleptik pada sari buah sangat dipengaruhi oleh suhu dan lamanya penyimpanan $[2,3]$. 
Pada penelitian ini akan diuji $\mathrm{pH}$ dan parameter yang digunakan pada uji karakteristik fisis yaitu massa jenis, ORP, TDS salinitas, resistivitas, konduktivitas serta uji organoleptik berupa uji rasa, warna dan bau.

\section{METODOLOGI PENELITIAN}

\section{Alat}

Alat yang digunakan dalam penelitian ini diantaranya seperangkat peralatan dapur (panci besar, sendok, pisau, baskom dan sebagainya), Blender, saringan, 1 set $\mathrm{pH}$ meter tipe SX751 dengan Portable pH/ORP/Conductivity/DO Meter, stopwatch, neraca digital dan Gelas ukur.

\section{Bahan}

Bahan yang akan digunakan diantaranya 1400 gram buah belimbing wuluh, 1400 gram gula pasir, 1,8 gram pengawet sintetis (natrium benzoat), 1,44 mg minyak cengkeh, dan $5600 \mathrm{ml}$ air.

\section{Prosedur Kerja}

Buah belimbing wuluh yang diambil adalah buah yang baik, tidak cacat dan tidak busuk. Buah dipilih berdasarkan keseragaman tingkat kematangannya, agar didapat hasil yang baik. Buah belimbing wuluh dicuci sampai bersih dengan menggunakan air biasa, pencucian yang kedua dilakukan dengan menggunakan air hangat, untuk memastikan kebersihan buah tersebut. Kemudian buah belimbing wuluh dipotong menjadi dua bagian dengan menggunakan pisau. Proses selanjutnya masukkan potongan buah ke dalam blender selama 10 menit. Setelah itu saring buah yang telah diblender untuk memisahkan sari buah dengan ampasnya.

Perbandingan antara buah belimbing wuluh, air, dan gula adalah 1: 4: 1. Berikut adalah resep dalam pembuatan sari buah belimbing wuluh dan perlakuan yang diberikan dengan variasi;

a. 200 gram belimbing wuluh $+800 \mathrm{ml}$ air + 200 gram gula pasir (tanpa natrium benzoat) (A1)

b. 200 gram belimbing wuluh +800 gram air + 200 gram gula pasir $+0,30$ gram natrium benzoat (A2) c. 200 gram belimbing wuluh +800 gram air + 200 gram gula pasir $+0,60$ gram natrium benzoat (A3)

d. 200 gram belimbing wuluh +800 gram air + 200 gram gula pasir+ 0,90 gram natrium benzoat (A4)

e. 200 gram belimbing wuluh +800 gram air + 200 gram gula pasir +4 tetes $(0,24 \mathrm{mg})$ minyak cengkeh (A5)

f. 200 gram belimbing wuluh +800 gram air + 200 gram gula pasir +4 tetes $(0,48 \mathrm{mg})$ minyak cengkeh (A6)

g. 200 gram belimbing wuluh +800 gram air + 200 gram gula pasir+ 6 tetes $(0,72 \mathrm{mg})$ minyak cengkeh (A7)

Gambar 1 Menunjukkan diagram alur penelitian dari pengujian sari buah belimbing wuluh. Langkah awal adalah pengolahan buah belimbing wuluh menjadi sari buah. Sari buah tersebut ditambahkan pengawet yaitu natrium benzoat dan minyak cengkeh untuk masingmasing sampel (A1 hingga A7).

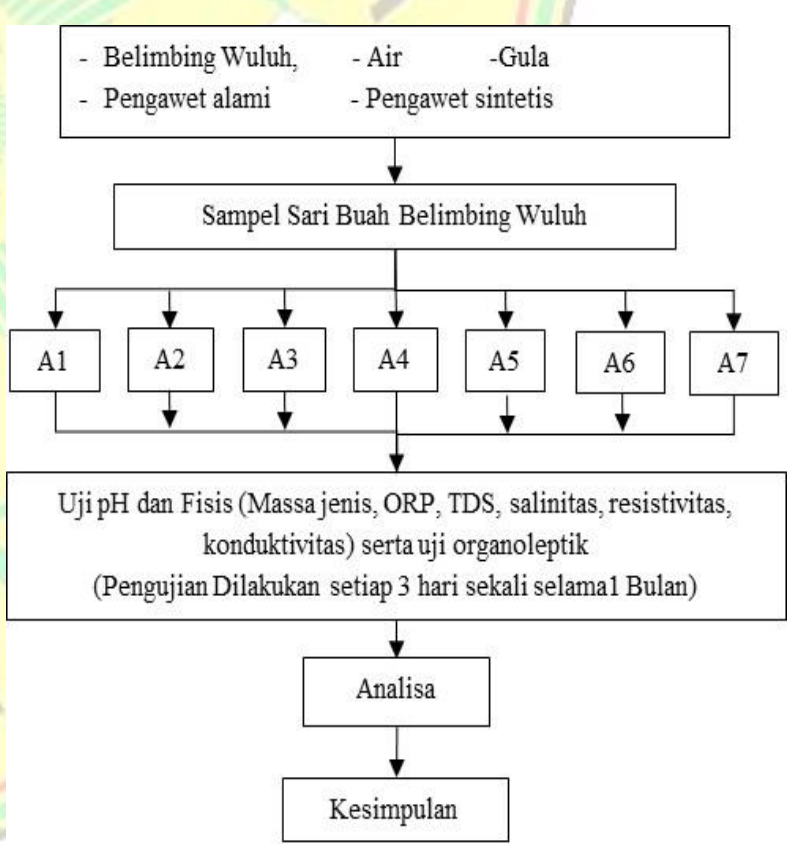

Gambar. 1. Diagram Alir Penelitian

\section{Uji pH}

Uji $\mathrm{pH}$ dilakukan dengan menggunakan $\mathrm{pH}$ meter. Pengujian $\mathrm{pH}$ yaitu dengan memasukkan alat pendeteksi nilai $\mathrm{pH}$ ke dalam sampel sari buah belimbing wuluh. Kemudian nilai $\mathrm{pH}$ dapat terbaca pada layar. Selanjutnya pengujian diulang sebanyak 3 kali. 


\section{Uji Massa Jenis}

Cara dari uji massa jenis yaitu dengan menimbang massa sari buah belimbing wuluh yang telah dimasukkan ke dalam gelas ukur menggunakan neraca digital. Kemudian massa gelas ukur kosong juga ditimbang untuk mencari massa dari sari buah blimbing wuluh. Dimana massa sari buah belimbing wuluh dapat diketahui dengan cara mengurangi massa sari buah belimbing wuluh dan gelas ukur denga massa gelas ukur kosong. Volume dari sari buah belimbing wuluh yang dimasukkan ke dalam gelas ukur adalah $25 \mathrm{ml}$.

\section{Uji ORP}

Uji ORP dilakukan dengan menggunakan probe ORP/meter. Caranya yaitu dengan menghubungkan probe ORP dengan layar pembaca nilai. Selanjutnya mamasukkan alat probe ORP ke dalam sari buah belimbing wuluh dan nilai dapat dilihat pada layar pembaca nilai ORP. Pengujian ORP dilakukan pengulangan sebanyak 3 kali.

\section{Uji Salinitas}

Uji salinitas dilakukan dengan probe salinity meter. Cara pengujiannya yaitu dengan memasukkan probe salinity meter ke dalam sari buah belimbing wuluh dan membaca nilainya pada layar. Dalam pengujian tersebut dilakukan pengulangan sebanyak 3 kali.

\section{Uji TDS (Tottal Disolve Solid)}

Uji TDS dilakukan dengan menggunakan probe TDS meter. Cara pengujiannya yaitu dengan memasukkan probe TDS meter ke dalam sari buah belimbing wuluh dan membaca nilai TDS pada layar. Uji TDS dilakukan pengulangan sebanyak 3 kali.

\section{Uji Resistivitas}

Uji resistivitas dilakukan dengan menggunakan probe resistiviity meter. Cara pengujiannya yaitu dengan memasukkan probe resistivitas meter ke dalam sari buah belimbing wuluh dan membaca nilai resistivitas pada layar. Pengujian dilakukan pengulangan sebanyak 3 kali.

\section{Uji Konduktivitas}

Uji konduktivitas dilakukan dengan menggunakan probe conductivity meter. Cara pengujiannya yaitu dengan memasukkan probe konduktivitas meter ke dalam sari buah belimbing wuluh dan membaca nilai konduktivitas pada layar. Dalam pengujian tersebut dilakukan pengulangan sebanyak 3 kali

\section{Uji Organoleptik}

Uji kesukaan pada warna, rasa, dan aroma dilakukan berdasarkan tingkat kesukaan konsumen. Dalam pengujian ini akan menggunakan 10 orang panelis tidak terlatih untuk memberi tanggapan atau penilaian uji hedonik pada sari buah belimbing wuluh, berdasarkan rentang nilai $1=$ Tidak suka, $2=$ Biasa, dan 3 Suka. Dalam uji ini 10 orang tersebut ditunjuk berdasarkan umur dan jenis kelamin untuk menentukan suka atau tidak suka terhadap sari buah belimbing wuluh. Usia panelis ditentukan mulai dari 25 tahun sampai 40 tahun, dengan jenis kelamin 3 laki-laki dan 7 perempuan.

\section{HASIL DAN PEMBAHASAN pH}

Pengukuran nilai $\mathrm{pH}$ merupakan salah satu parameter untuk melihat tingkat keasaman suatu produk pangan. Gambar 2 menunjukkan hasil dari Nilai $\mathrm{pH}$ pada sampel A1 hingga A7. Nilai pH sampel A1 dihari pertama lebih kecil dibandingkan dengan sampel lainnya yaitu A2 hingga A7. Sedangkan pada sampel A2 hingga A4 yang merupakan sampel dengan penambahan pengawet sintetis, nilai $\mathrm{pH}$ semakin besar berdasarkan jumlah penambahan pengawet pada sampel sari buah belimbing wuluh.

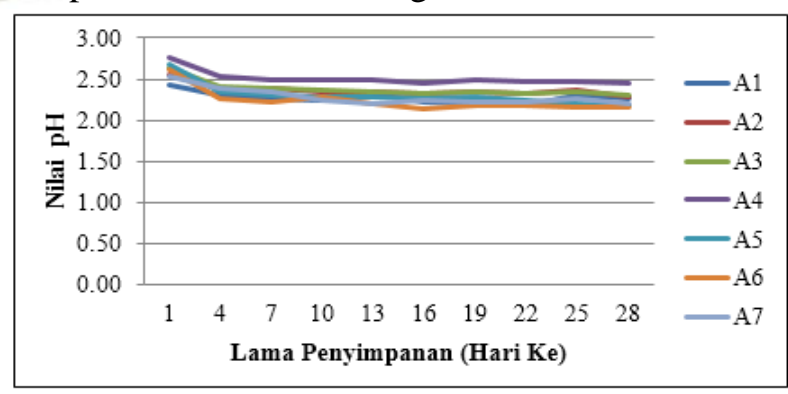

Gambar. 2. Hubungan Nilai pH Sari Buah Belimbing Wuluh Dengan Lama Penyimpanan 
Sehingga nilai $\mathrm{pH}$ pada sampel A4 merupakan nilai $\mathrm{pH}$ terbesar dibandingkan dengan semua sampel. Untuk sampel A5 hingga A7 yang merupakan sampel dengan penambahan pengawet alami, nilai $\mathrm{pH}$ semakin menurun seiring dengan penambahan jumlah pengawet alami.

Penambahan pengawet sintetis mengakibatkan nilai $\mathrm{pH}$ belimbing wuluh meningkat, hal ini dapat disebabkan oleh pengawet sintetis yang dapat meningkatkan keefektifan penghambatan perkembangbiakan mikroorganisme. Dengan adanya penghambatan perkembangbiakan mikroorganisme, maka makin rendah pula aktivitas mikroorganisme yang dapat mengubah gula menjadi asam dan alkohol.

Sedangkan dengan semakin banyak jumlah penambahan pengawet alami, nilai $\mathrm{pH}$ justru semakin rendah. Dimana semakin sedikit jumlah penambahan pengawet alami nilai $\mathrm{pH}$ semakin tinggi. Maka, dengan hal tersebut maka selain jumlah penambahan gula pada sari buah belimbing wuluh, penambahan pengawet sintetis dan pengawet alami juga dapat mempengaruhi nilai $\mathrm{pH}$. Sehingga dengan demikian nilai $\mathrm{pH}$ diperngaruhi oleh penambahan pengawet sintetis [4].

Berdasarkan lamanya penyimpanan semakin lama maka nilai $\mathrm{pH}$ semakin menurun. Dan jika dilihat dari segi penambahan jenis pengawet, yaitu pengawet sintetis dan pengawet alami terdapat perbedaan pada nilai $\mathrm{pH}$ tersebut. Dimana dengan semakin banyak penambahan pengawet sintetis, maka semakin tinggi nilai $\mathrm{pH}$ tersebut.

\section{Massa Jenis}

Massa jenis merupakan tingkat kemurnian dari suatu cairan. Gambar 3 menunjukkan jika nilai massa jenis pada semua sampel berada pada rentang $1037-1060 \mathrm{~g} / \mathrm{cm}^{3}$. Dimana rentang nilai tersebut terdapat pada semua sampel dan lamanya penyimpanan. Untuk sampel A1 merupakan sampel tanpa penambahan pengawet. Dimana dari hari pertama menunjukkan nilai massa jenis yang lebih kecil dibandingkan dengan sampel lainnya.
Untuk nilai massa jenis pada sampel dengan penambahan pengawet sintetis yaitu A2, A3, A4 dihari pertama memiliki nilai yang lebih besar dibandingkan sampel A1.

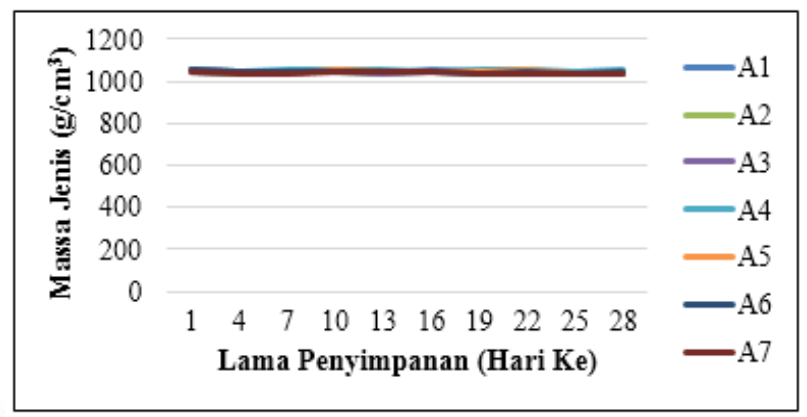

Gambar. 3. Hubungan Nilai Massa Jenis Sari Buah Belimbing Wuluh Dengan Lama Penyimpanan

Sampel dengan penambahan pengawet alami yaitu A5, A6, A7 memiliki nilai massa jenis yang hampir sama dengan sampel A2, A3 dan 4, serta lebih besar dibandingkan dengan sampel A1.Nilai massa jenis pada semua sampel cenderung sama berdasarkan lamanya penyimpanan. Kemudian perbedaan nilai antara sampel satu dengan sampel lainnya tidak terlalu jauh. Dengan hasil tersebut maka penambahan pengawet sintetis dan pengawet alami tidak mempengaruhi nilai massa jenis pada sari buah belimbing wuluh.

\section{ORP}

ORP merupakan suatu nilai untuk mengetahui kemampuan oksidasi suatu bahan. Gambar 4. menunjukkan hasil dari nilai ORP. Dari gambar tersebut terlihat jika nilai ORP pada sampel A1 hingga A7 hari pertama sampai hari ke-28 menunjukkan bahwa, masing-masing sampel memiliki nilai ORP yang berbeda-beda. Pada hari pertama, sampel A1 (tanpa pengawet) nilai ORP lebih rendah dibandingkan dengan sampel yang menggunakan penambahan pengawet. Dan semakin banyak jumlah pengawet yang ditambahkan, yaitu pengawet sintetis (A2, A3, A4) dan pengawet alami (A5, A6, A7) maka semakin tiinggi nilai ORP pada sari belimbing wuluh.

Sampel A2, A3 dan A4 ternyata menunjukkan bahwa, semakin tinggi kadar pengawet sintetis nilai ORP juga semakin tinggi, 
begitu juga pada sampel A5, A6, dan A7 yang menggunakan pengawet alami jika semakin tinggi kadar pengawet alami nilai ORP juga semakin tinggi. Kemudian pada hari keempat hingga hari terakhir pengujian nilai ORP sampel A1 masih tetap lebih rendah jika dibandingkan dengan sampel dengan penambahan pengawet sintetis. Dimana dengan semakin banyak penambahan pengawet sintetis nilai ORP semakin tinggi.

Sedangkan berdasarkan lamanya penyimpanan nilai ORP pada semua sampel tidak mengalami perubahan yang cukup jauh. Untuk sampel dengan penambahan pengawet alami, nilai ORP pada hari keempat hingga hari terakhir memiliki kecenderungan naik. Akan tetapi dengan semakin banyak jumlah penambahan pengawet alami, maka nilai ORP semakin rendah.

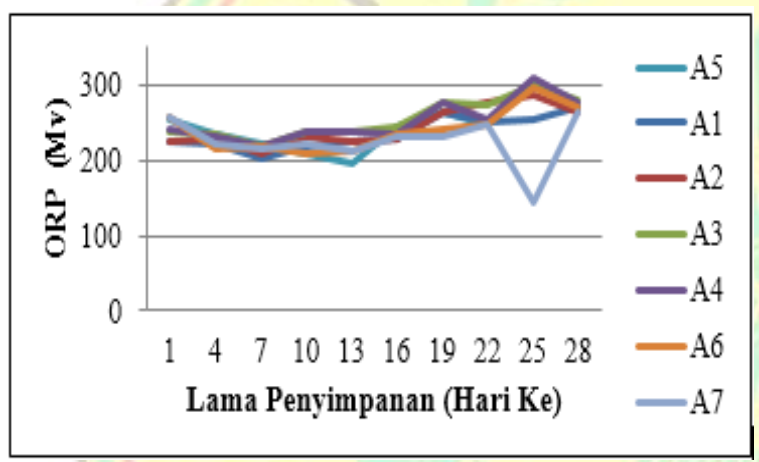

Gambar. 4. Hubungan Nilai ORP Sari Buah Belimbing Wuluh Dengan Lama Penyimpanan

Kemudian pada hari ke-25 nilai ORP untuk sampel 7 lebih rendah dibandingkan dengan sampel lainnya. Hal tersebut dapat disebabkan karena sampel tersebut ditambahkan dengan pengawet alami yang lebih banyak dibandingkan sampel lainnya. Nilai ORP yang semakin meningkat jika disimpan semakin lama. Ini menunjukkan bahwa sari buah belimbing mengalami proses oksidasi dan konsentrasi suatu bahan kimia.

Perubahan nilai ORP dipengaruhi oleh lamanya penyimpanan dan penambahan zat pengawet kedalam sampel. Semakin tinggi nilai ORP maka akan semakin lama waktu yang dibutuhkan untuk membunuh bakteri yang terdapat pada sari buah tersebut. Sehingga sari buah belimbing wuluh akan semakin cepat rusak (basi) [5].

\section{Total Disolve Solid (TDS)}

Hasil dari nilai TDS sari buah belimbing wuluh ditunjukkan pada Gambar 5. Dalam gambar tersebut menunjukkan jika sampel A1 hingga A7 memiliki nilai yang tidak sama pada setiap pengujian. Akan tetapi jika dilihat lebih detail dair nilai TDS tersebut maka terdapat sedikit perbedaan.

Perbedaan nilai TDS tersebut disebabkan karena penambahan jenis pengawet pada sampel sari buah belimbing wuluh tersebut. Untuk sampel dengan penambahan pengawet sintetis, nilai TDS memiliki kecenderungan yang menurun berdasarkan jumlah penambahan pengawet sintetis. Semakin banyak pengawet sintetis yang ditambahkan, maka semakin kecil nilai TDS dari sari buah belimbing wuluh. Hal tersebut dapat dilihat pada sampel A2, A3 dan A4, dimana nilai TDS memiliki kecenderungan yang menurun berdasarkan jumlah penambahan pengawet sintetis.

Sampel A1 merupakan sampel tanpa penambahan pengawet. Dimana dari hari pertama hingga hari terakhir menunjukkan nilai massa jenis yang lebih kecil dibandingkan dengan sampel lainnya. Untuk sampel lain yaitu sampel dengan penambahan pengawet sintetis (A2, A3, A4) dan pengawet alami (A5, A6, A7) memiliki nilai massa jenis yang lebih besar dibandingkan dengan sampel A1. Untuk penambahan pengawet alami, nilai TDS justru cenderung meningkat.

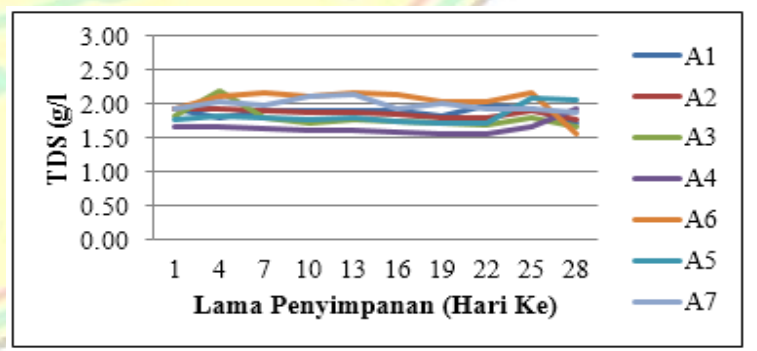

Gambar. 5. Hubungan Nilai TDS Sari Buah Belimbing Wuluh Dengan Lama Penyimpanan

Jika semakin banyak penambahan jumlah pengawet alami, maka nilai TDS dari sari belimbing wuluh semakin meningkat. Hal tersebut dapat dilihat pada sampel A5, A6 dan A7, dimana nilai TDS cenderung meningkat berdasarkan jumlah penambahan pengawet alami. Dengan demikian maka penambahan jenis 
pengawet yaitu pengawet sintetis dan pengawet alami mepengaruhi nilai TDS dari sari buah belimbing wuluh. Dan nilai TDS tersebut masih berada di bawah standar yang ditetapkan dalam SNI (Standar Nasional Indonesia [6].

\section{Salinitas}

Kadar garam dalama suatu cairan (bahan) dapat dilihat dari tinggi rendahnya nilai salinitas dalam cairan (bahan) tersebut. Gambar 6 menunjukkan hasil dari nilai salinitas sari buah belimbing wuluh. Dari gambar tersebut terlihat jika nilai salinitas berada untuk semua sampel dan semua pengujian berada pada rentang 1,11 - 1,50 ppt. Akan tetapi, Jika dilihat secara berdasarkan penambahan jenis pengawet, maka nilai salinitas dari sari belimbing wuluh terdapat perbedaan.

Untuk sampel dengan penambahan pengawet sintetis, nilai salinitas cenderung menurun berdasarkan jumlah penambahan pengawet sintetis. Dimana semakin banyak pengawet sintetis yang ditambahkan, maka semakin kecil nilai salinitas pada sari buah belimbing wuluh. Hal tersebut dapat dilihat pada sampel A2, A3 dan A4, dimana nilai salinitas cenderung menurun berdasarkan jumlah penambahan pengawet sintetis.

Sedangkan untuk penambahan pengawet alami, nilai salinitas cenderung meningkat. Dimana semakin banyak penambahan jumlah pengawet alami, maka akan semakin meningkat nilai salinitas pada sari belimbing wuluh. Hal tersebut dapat dilihat pada sampel A5, A6 dan A7, dimana nilai salinitas cenderung meningkat berdasarkan jumlah penambahan pengawet alami.

Dengan hasil tersebut maka penambahan jenis pengawet yaitu pengawet sintetis dan pengawet alami memberikan pengaruh terhadap nilai salinitas pada sari buah belimbing wuluh. Dimana kedua jenis pengawet tersebut memiliki pengaruh yang berbeda pada sari buah belimbing wuluh.

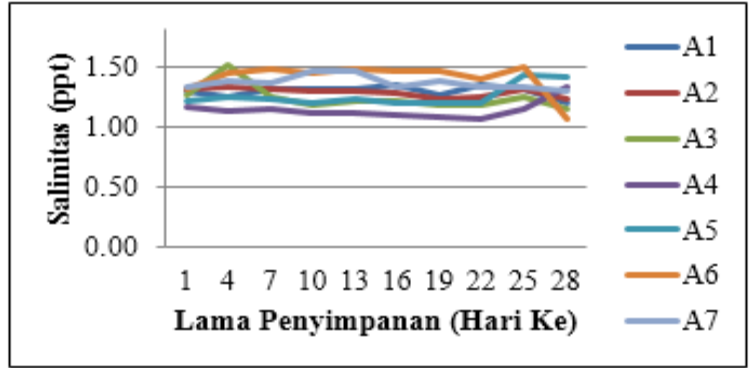

Gambar.6. Hubungan Nilai Salinitas Sari Buah Belimbing Wuluh Dengan Lama Penyimpanan

\section{Resistivitas}

Resistivitas adalah kemampuan suatu bahan untuk menghambat arus listrik. Semakin besar nilai resistivitas suatu bahan maka akan semakin besar kemampuannya dalam menghambat arus listrik. Gambar 7 menunjukkan jika nilai resistivitas pada semua sampel berubah-ubah pada setiap pengujian. Begitu juga nilai resistivitas antara sampel yang berbeda-beda.

Untuk sampel A1 dihari pertama nilai resistivitas cukup tinggi dan dihari ke-16 nilai menurun cukup jauh. Penurunan nilai tersebut dapat disebabkan adanya perbedaan suhu pada saat pengujian.

Untuk sampel A2, A3, dan A4 merupakan sampel dengan penambahan pengawet sintetis. Nilai resistivitas dari ketiga sampel tersebut menunjukkan nilai yang menurun seiring bertambahnya dengan jumlah penambahan pengawet sintetis.

Berdasarkan hasil pada hari pertama dari ketiga sampel tersebut, semakin banyak penambahan jumlah pengawet sintetis, maka semakin rendah nilai resistivitas sari buah belimbing wuluh. Sedangkan dihari keempat hingga hari ke-28 (hari terakhir) nilai resistivitas mengalami ketidakstabilan pada setiap pengujian. Seperti yang terlihat dihari keempat untuk sampel A3 yang mengalami penurunan cukup signifikan. Hal tersebut dapat disebabkan karena adanya perbedaan suhu pada setiap pengujian.

Untuk sampel dengan penambahan pengawet alami yaitu A5, A6 dan A7 pada hari pertama, nilai resistivitas semakin besar berdasarkan bertambahnya jumlah penambahan pengawet alami. Dimana semakin banyak jumlah 
penambahan pengawet alami, maka semakin besar nilai resistivitas tersebut. Akan tetapi, dihari keempat hingga hari ke-28 (hari terakhir) nilai resistivitas juga mengalami ketidakstabilan pada setiap pengujian seperti sampel lainnya.

Perbedaan nilai resistivitas juga disebabkan karena adanya perbedaan suhu pada setiap pengujian. Dengan hasil tersebut maka penambahan jenis pengawet tidak mempengaruhi nilai resistivitas pada sari buah belimbing wuluh.

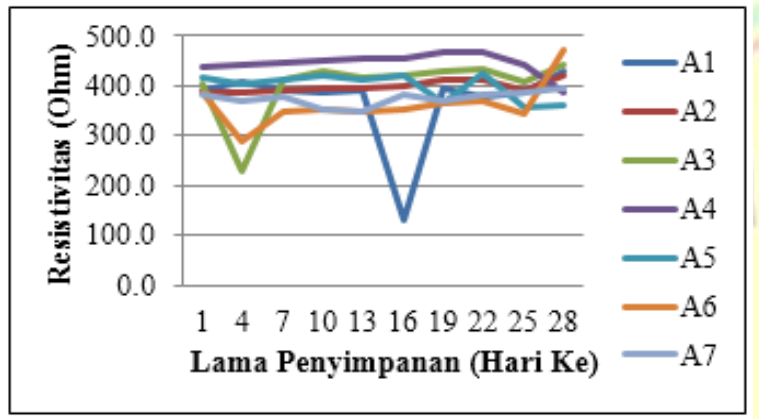

Gambar. 7. Hubungan Nilai Resistivitas Sari Buah Belimbing Wuluh Dengan Lama Penyimpanan

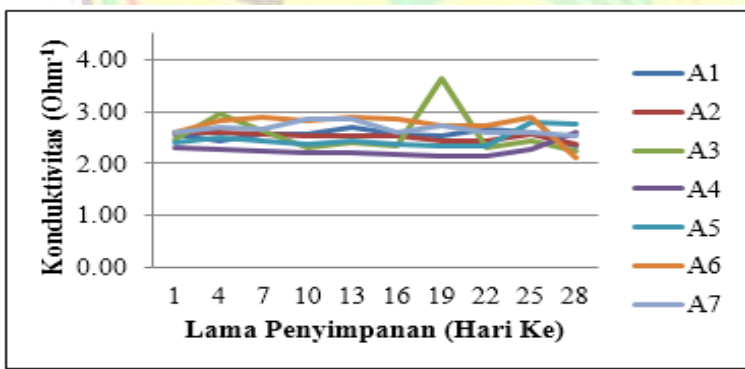

Gambar. 8. Hubungan Nilai Konduktivitas Sari Buah Belimbing Wuluh Dengan Lama Penyimpanan

\section{Konduktivitas}

Konduktivitas listrik menunjukkan tingkat kemampuan suatu bahan untuk menghantarkan listik. Semakin asam suatu bahan maka konduktivitasnya semakin tinggi.

Sampel A3 dan A4 nilai konduktivitasnya akan semakin naik jika disimpan lebih lama walaupun perubahan nilainya tidak terlalu jauh. Ini berarti menunjukkan bahwa penambahan pengawet sintetis selama penyimpanan dapat meningkatkan nilai konduktivitas listrik. Dan pada hari ke-19 nilai konduktivitas sampel A3 naik cukup jauh dari hari sebelumnya.

Naiknya nilai konduktivitas dapat disebabkan karena perbedaan suhu pada saat pengujian nilai konduktivitas. Dengan semakin tinggi nilai konduktivitasnya maka tingkat keasamannya akan semakin tinggi, hal tersebut menunjukkan bahwa semakin asam suatu cairan sifat kelistrikannya akan semakin baik.

Hubungan antara resistivitas dan konduktivitas untuk sampel A1 hingga A7 menunjukkan nilai yang sesuai yaitu, semakin tinggi nilai resistivitas maka nilai konduktivitasnya akan semakin rendah. Gambar 4.7 menunjukkan nilai konduktivitas sari buah belimbing wuluh berdasarkan lamanya penyimpanan.

\section{Organoleptik}

Hasil uji organoleptik dari segi warna pada hari pertama hingga hari terakhir pengujian, secara keseluruhan panelis menyatakan tingkat kesukaannya terhadap sampel A2 hingga A4. Dimana sampel A2 hingga A4 merupakan sampel dengan penambahan pengawet sintetis yaitu natrium benzoat.

Kemudian untuk sampel A1 yang merupakan sampel tanpa penambahan pengawet, panelis hanya menyukai warna sampel tersebut dihari pertama saja. Kemudian dihari keempat hingga hari terakhir panelis sudah tidak menyukainya lagi. Dan untuk sampel A5 hingga A7 aroma sampel tidak disukai oleh panelis dari hari pertama. sampel A5 hingga A7 merupakan sampel dengan penambahan pengawet alami yaitu minyak cengkeh.

Panelis tidak menyukai warna dari ketiga sampel tersebut dikarenakan warnanya yang keruh karena pencampuran minyak cengkeh tersebut.

Dari segi rasa dihari pertama sampel A1 hingga A4 disukai oleh semua panelis. Kemudian pada hari keempat sampel A1 sudah terasa sangat asam (basi), sehingga para panelis tidak menyukainya. Rasa tersebut tersebut bertahan hingga hari terakhir penyimpanan. Hal tersebut dikarenakan sampel tidak ditambahkan dengan pengawet dan sampel dihari ke-empat sudah basi.

Kemudian untuk sampel dengan penambahan pengawet sintetis rasa dari sampel tersebut disukai hingga hari terakhir penyimpanan. Sedangkan untuk sampel dengan penambahan pengawet alami, hanya disukai hingga hari 
keempat dan tidak disukai pada hari ketujuh hingga hari terakhir penyimpanan. Hal tersebut dikarenakan sampel dengan penambahan pengawet alami merupakan minyak cengkeh. Minyak merupakan salah satu bahan yang mudah teroksidasi. Sehingga dari segi aroma sampel sudah berbau tidak enak, kemudian rasa juga tidak enak dan warna lebih keruh dibandingkan dengan sampel dengan penambahan pengawet sintetis.

Dengan hasil tersebut, maka antara rasa dengan aroma berbanding lurus. Dimana ketika aroma disukai, maka rasa juga disukai oleh panelis. Dan penambahan pengawet memberikan pengaruh rasa dan aroma pada sari buah belimbing wuluh. Gambar 9, 10 dan 11 menunjukkan hasil dari pengujian aroma, rasa, dan warna dari sari buah belimbing wuluh berdasarkan lamanya penyimpanan

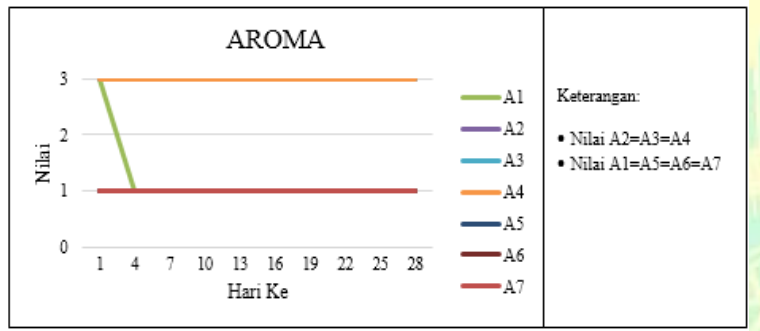

Gambar. 9. Hubungan Aroma Sari Buah Belimbing Wuluh Dengan Lama Penyimpanan

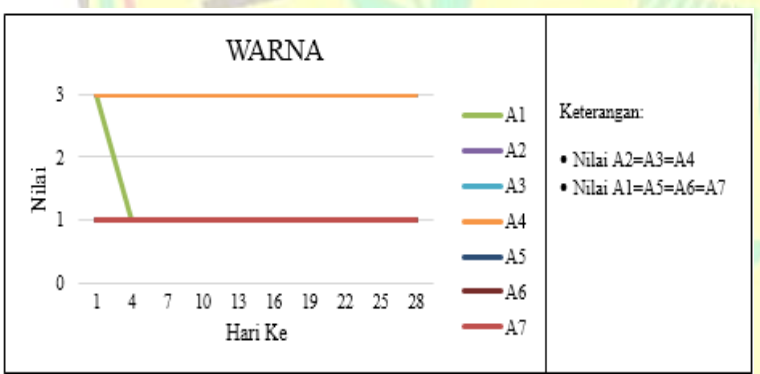

Gambar. 10. Hubungan Warna Sari Buah Belimbing Wuluh Dengan Lama Penyimpanan

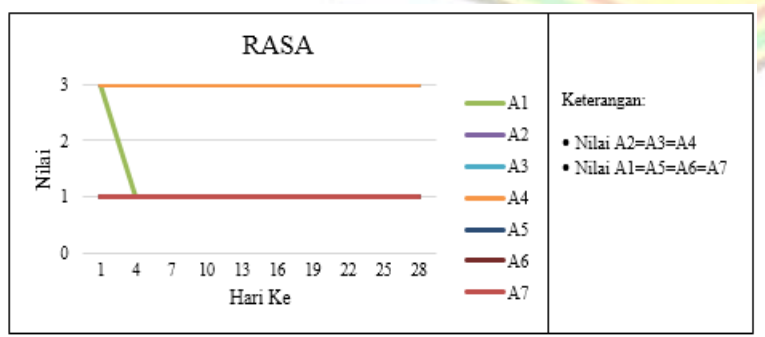

Gambar. 11. Hubungan Rasa Sari Buah Belimbing Wuluh Dengan Lama Penyimpanan

\section{KESIMPULAN}

Berdasarkan hasil penelitian uji $\mathrm{pH}$ dan karakteristik fisis sari buah belimbing wuluh, dapat diambil kesimpulan diantaranya.

1. Penambahan pengawet sintetis dan pengawet alami pada sari buah belimbing wuluh secara keseluruhan tidak meningkatkann nilai $\mathrm{pH}$. Untuk semua sampel yang telah diberi pengawet sintetis nilai $\mathrm{pH}$ masih berada di bawah SNI

2. Ada peningkatan $\mathrm{pH}$ pada sari buah belimbing wuluh yang telah ditambah pengawet sintetis dan terdapat penurunan nilai $\mathrm{pH}$ pada sampel yang ditambah pengawet alami.

3. Dengan penambahan pengawet tidak mempengaruhi massa jenis dari sari buah belimbing wuluh (sampel A1 hingga A7).

4. Penambahan pengawet sintetis menyebabkan penurunan nilai salinitas dan TDS, sedangkan penambahan pengawet buatan menyebabkan peningkatan nilai salinitas dan TDS pada sari buah belimbing wuluh.

5. Penambahan pengawet pengawet sintetis dan pengawet alami tidak mempengaruhi nilai resistivitas dan konduktivitas pada sari buah belimbing wuluh (sampel A1 hingga A7).

6. Pada uji organoleptik penambahan pengawet sintetis (sampel A2, A3, dan A4) lebih banyak disukai dibandingkan dengan penambahan pengawet alami (sampel A5, A6, dan A7).

\section{DAFTAR PUSTAKA}

Latifah, Q.A. 2008. "Antibakteri Pada Buah Belimbing Wuluh (Averrhoa Bilimbi L.) Dengan Variasi Pelarut". Skripsi Fakultas Sains Dan Teknologi Universitas Islam Negeri (UIN) Malang.

Lutpiah, N.E. 2005. "Karakteristik Fisis Dan Nilai Ph Jus Belimbing Yang Disimpan Pada Suhu Kamar Dan Lemari Pendingin". Skripsi Fakultas Matematika Dan Ilmu Pengetahuan Alam. Institut Pertanian Bogor.

Mariance, R. 2006. "Karakteristik fisis, pH dan organoleptik Sari Wortel”, Skripsi Fakultas 
Matematika Dan Ilmu Pengetahuan Alam Institut Pertanian Bogor.

Purwaningsih, E. 2007. "Multiguna Belimbing

Wuluh". Exact Ganeka. Jakarta.
Quality Assurance Departement. PT Ades Waters Indonesia Tbk.

Standaar Nasional Indonesia. 1992. Minuman Sari Buah (Squash). SNI 01-2984-1992.

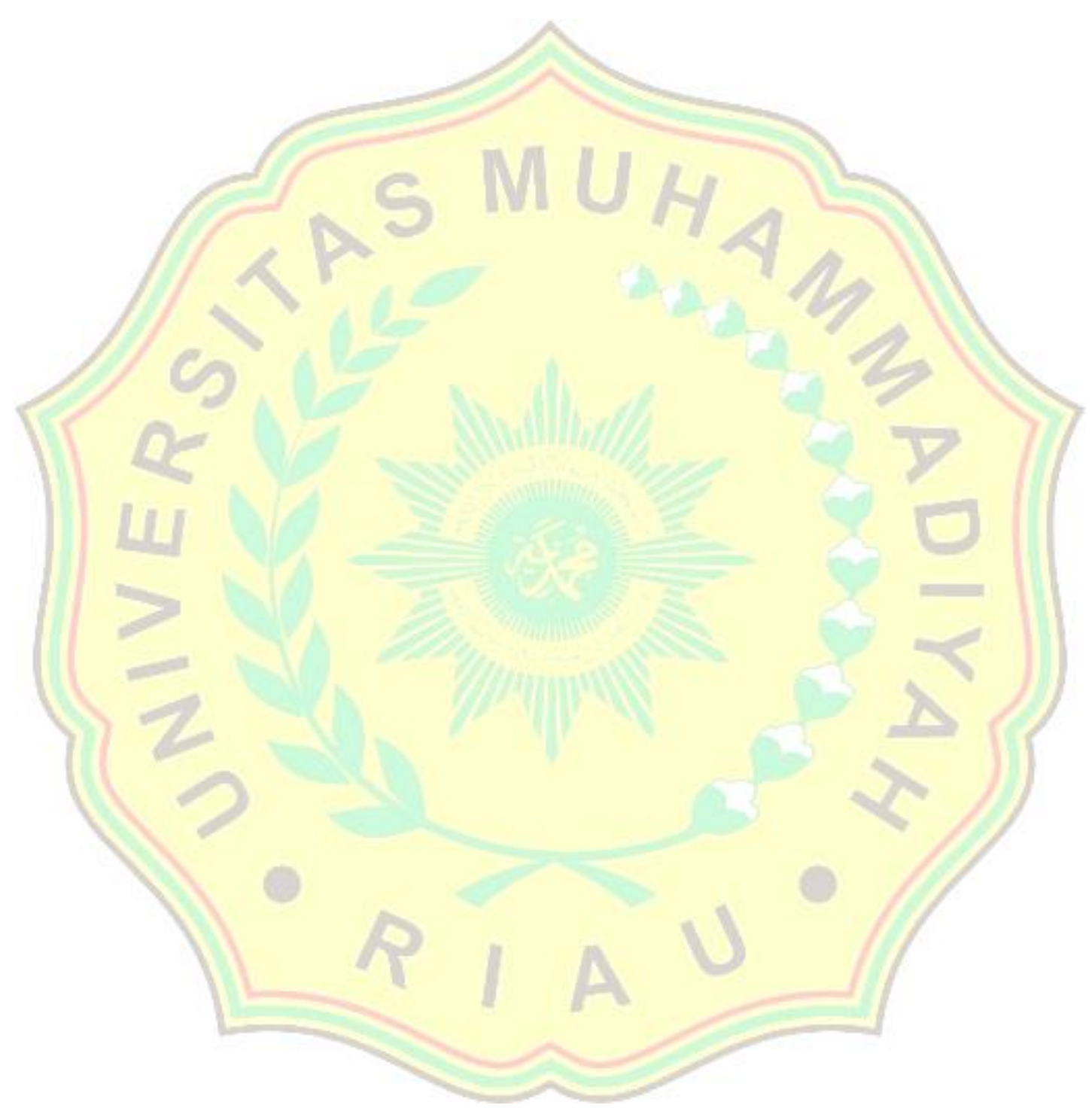


